\title{
NAFKAH IDDAH AKIBAT TALAK BA`IN DALAM PERSPEKTIF KEADILAN GENDER (ANALISIS TERHADAP HUKUM PERKAWINAN INDONESIA)
}

\author{
Fadhilatul Maulida \\ LKKBH Payakumbuh, fadbilatulmaulida570@gmail.com \\ Busyro \\ Fakultas Syariah LAIN Bukittinggi, busyro.pro18@gmail.com
}

\begin{tabular}{|c|c|c|}
\hline Diterima: 25Juli 2018 & Direvisi : 20 November 2018 & Diterbitkan: 30 Desember 2018 \\
\hline
\end{tabular}

\begin{abstract}
Iddah is one of the obligations for a wife who is divorced by her husband, whether divorce is caused by divorce from a busband or because of a wife's lawsuit to the court (khulu'). While undergoing iddah, the wife has the right to obtain housing and living facilities, as is the case in raj'i talak. On the other hand, in the Talak $B a^{\prime}$ in, the Islamic marriage law in Indonesia does not provide an opportunity for the wife to earn a living even though she has to undergo the same obligation, namely undergoing iddah and living in her husband's house. This is certainly not in line with gender justice that carries the equality of men and women in this life. Judging from the thoughts of the ulema of the school of thought, actually the legal thinking of Imam Abu Hanifah had first argued to give the wife the right to earn a living in divorce even though the divorce was in the form of divorce. It seems that Imam Abu Hanifah's opinion should be considered in the renewal of Islamic marriage law in Indonesia, especially in realizing justice to the women in their marriage and divorce.
\end{abstract}

Keywords: nafkah, iddah, gender equity, Indonesian Marriage Law

\begin{abstract}
Abstrak
Iddah merupakan salah satu kewajiban bagi seorang istri yang diceraikan oleh suaminya, baik perceraian yang disebabkan oleh talak dari suami atau karena gugatan istri ke pengadilan (kbulu'). Selama menjalani iddah, maka istri berbak untuk mendapatkan fasilitas tempat tinggal dan nafkah, begitu yang berlaku dalam talak raj'i. Sebaliknya dalam talak ba in, bukum perkawinan Islam di Indonesia tidak memberikan peluang kepada istri untuk. mendapatkan nafkah walaupun harus menjalani kewajiban yang sama, yaitu menjalani iddah dan tinggal di rumah suaminya. Hal ini tentu tidak sejalan dengan keadilan gender yang mengusung persamaan laki-laki dan perempuan dalam kebidupan ini. Dilihat dari pemikiran ulama mazhbab, sebenarnya pemikiran bukum Imam Abu Hanifah telab terlebih dabulu berpendapat untuk memberikan bak nafkah kepada istri dalam perceraianny walaupun perceraian itu dalam bentuk. talak ba in. Sepertinya pendapat Imam Abu Hanifah sudah seyogyanya dipertimbangkan dalam pembaruan bukum perkawinan Islam di Indonesia khususnya dalam mewnjudkan keadilan kepada pihak perempuan dalam perkawinan dan perceraian mereka.
\end{abstract}

Kata Kunci: nafkah, iddah, keadilan gender, bukum perkawinan Indonesia

\section{PENDAHULUAN}

Perkawinan adalah ikatan lahir batin antara sepasang suami istri untuk mendapatkan kebahagiaan dalam hidup berumah tangga. Kuatnya ikatan itu tercermin dalam Undangundang Republik Indonesia Nomor 1/1974 tentang perkawinan yang mempersulit terjadinya perceraian. ${ }^{1}$ Walaupun demikian, tidak semua perkawinan dapat dapat bertahan

${ }^{1}$ Lihat penjelasan Umum Undang-Undang Nomor 1 Tahun 1974 Tentang Perkawinan lama, dan harus diakhiri di tengah jalan karena sebab-sebab tertentu, seperti pertengkaran yang tak kunjung usai, ketidakcocokan satu sama lain, dan sebab-sebab lainnya. Dalam menangani permasalahan keluarga ini, ada pasangan yang dapat mengatasinya, bersabar dan menahan diri dan mau menerima nasehat satu sama lain. Sebaliknya ada juga suami istri yang tidak dapat mengatasi problematika ini sehingga berakibat terjadinya perceraian.

Perceraian atau talak telah dibahas oleh 
ulama dalam kitab-kitab fiqh mereka, dan mereka berbeda dalam menetapkan hukum talak. Jumhur Ulama berpendapat bahwa talak pada dasarnya boleh namun lebih bagus ditinggalkan. ${ }^{2}$ Ibn al-Humam dari Hanafiyah mengatakan bahwa yang paling benar adalah talak terlarang kecuali dengan alasan yang benar, sedangkan Ibnu Abidin berpendapat bahwa sekalipun dibencinya talak tidak bisa menghilangkan kebolehan talak namun minimal hukumnya makruh. Terlepas dari perbedaan pemikiran hukum ulama di atas, pada prinsipnya perceraian dilarang, bahkan Sayyid Sâbiq mengatakan bahwa talak adalah bentuk kufur nikmat sedangkan kufur nikmat adalah haram sehingga tidak halal bercerai kecuali dalam kondisi dharurat. ${ }^{3}$ Terlarangnya talak terlihat dari isyarat Rasulullah dalam hadis riwayat Abû Dâwûd yang menyatakan bahwa talak merupakan sesuatu yang halal namun sangat dibenci. ${ }^{4}$

Dalam kitab fiqh disebutkan bahwa perceraian bisa berasal dari keinginan suami yang disebut talak dan bisa berasal dari keingian istri yang disebut dengan khulu'. Dalam konteks modern di Indonesia kedua bentuk peceraian itu harus diajukan ke Pengadilan Agama melalui permohonan talak oleh suami atau gugatan cerai oleh istri. Apabila dikabulkan, maka kepada suami diberikan putusan untuk mengikrarkan talak dan untuk gugatan istri talak dijatuhkan atau diputuskan oleh pengadilan tersebut. Hal ini berdasarkan ijtihad ulama dan telah banyak diterapkan di berbagai negara seperti Mesir, Suriah dan Indonesia. ${ }^{5}$

Dalam Islam telah diatur akibat hukum

2 Wahbah al-Zuhaylî, al-Fiqh al-Islâmî wa Adillatubu, Juz 7, (Beirut: Dâr al-Fikr, 1989), h. 362

3 Sayyid Sâbiq, Fiqh al-Sunnah, (Beirut: Dâr alFikr, 1992), h. 9

4 Jalâl al-Dîn al-Suyûthî, al-Jâmi' al-Shaghîr, (Bandung: al-Ma'arif, [tth].), h. 5

5 Ketentuan talak yang dijatuhkan oleh pengadilan diatur dalam Pasal 5 Undang-undang Mesir Nomor 25 tahun 1920, pasal 111 Undang-undang Suriha dan Pasal 119 ayat 2 Kompilasi Hukum Islam pasca perceraian, yakni adanya hak- hak istri, di antaranya adalah hak untuk mendapatkan nafkah iddah, tempat tinggal dan kiswah (pakaian) selama dalam masa iddah. Ulama fiqh sepakat bahwa untuk perempuan yang statusnya dalam talak raj'i diberikan hak untuk mendapatkan nafkah dan fasilitas tempat tinggal. Namun untuk talak ba`in, terjadi perbedaan pendapat, baik karena talak tiga maupun karena khulu'. Ulama Hanafiyah mengatakan bahwa untuk istri yang ditalak secara ba'in tetap mempunyai hak untuk mendapatkan nafkah dan maskan (tempat tinggal) sama halnya dengan perempuan yang ditalak raj'i. Alasanya karena perempuan tersebut dia harus menghabiskan masa tunggunya (iddah) di rumah suaminya. ${ }^{6}$ Nafkahnya ini adalah hutang yang dibebankan kepada suaminya sejak jatuhnya talak. Hutang ini tidak dapat dianggap lunas kecuali sudah dibayar oleh suaminya atau direlakan oleh istri.

Ulama Hanabilah mengatakan bahwa istri tidak mempunyai hak untuk mendapatkan nafkah dan maskan (tempat tinggal), seperti yang tertulis dalam hadis Fatimah binti Qais bahwa ia telah dijatuhkan talak tiga oleh suaminya. Lalu Rasul SAW bersabda kepadanya (Fatimah) engkau tidak ada hak nafkah dari padanya (suaminya). ${ }^{7}$ Sedangkan ulama Syâfi'iyah dan Mâlikiyah mengatakan bahwa istri hanya berhak mendapatkan hak tempat tinggal, sedangkan untuk nafkah dilihat apakah ia hamil atau tidak. Sebab kehamilanlah yang membuatnya mendapatkan nafkah. ${ }^{8}$

Bagi umat Islam di Indonesia hukum yang diberlakukan adalah Undang-undang RI No. 1/1974 dan Kompilasi Hukum Islam (KHI). Pada pasal 149 (b) KHI disebutkan bahwa istri tidak mendapatkan hak nafkah

${ }^{6}$ Abû Bakar ibn Mas'ûd al-Kasânî, al-Badâi’' alShanâ'i, juz 4, (Beirut: Dâr al-Kutub al-Ilmiyah, 2010), h. 16

${ }^{7}$ Muwaffiq al-Dîn ibn Qudâmah, al-Mughnî, juz 11, (Kuwait: Dâr 'Alim al-Kutub, 1997), h. 606

8 Ahmad ibn Muhammad al-Dardiri, al-Syarh alShaghir, (t.tp, t.p, t.th), Juz 2, h. 740 
iddah, maskan dan kiswah dalam talak ba in dan dalam keadaan istri nusyuz. Hak nafkah hanya didapatkan apabila perceraian tersebut merupakan talak raj'i (suami yang mengajukan), dan itupun selama penyebab permohonan talak bukan karena istri nusyuz. Dengan demikian istri yang diceraikan selalu mendapatkan keadilan berupa hak nafkah selama masa iddah.

Sepertinya ada ketidakadilan gender dalam aturan undang-undang yang menegasikan hak nafkah bagi istri dari mantan suaminya dalam talak bain. Ketidakadilan tersebut terlihat ketika seorang istri yang diikat dengan iddah, tidak boleh menikah untuk sementara waktu dengan orang lain, dan harus menetap di rumah suaminya tapi tidak diberi hak nafkah. Seolah-olah seorang perempuan mendapatkan hukuman dengan adanya perceraian tersebut. Sedangkan laki-laki tidak mendapatkan sanksi apa-apa ketika ia mentalak istrinya dengan talak bain atau disebabkan oleh khulu'. Walaupun keinginan bercerai itu dari si istri, tentulah penyebabnya adalah suaminya juga. Kadang-kadang pengajuan khulu' oleh istri disebabkan dia telah diceraikan oleh suaminya di bawah tangan dan atau telah ditelantarkan oleh suaminya tanpa dinafkahi sekian lama.

Ketentuan itu sepertinya mengusik rasa keadilan gender yang dialamatkan kepada perempuan, apalagi secara tegas pasal 119 ayat 2 KHI mengatakan bahwa setiap talak yang dijatuhkan oleh Pengadilan Agama adalah talak ba in. Ketentuan ini berbeda dengan ketentuan dalam Undang-undang Mesir ${ }^{9}$ dan Suriah yang menetapkan bahwa talak yang dijatuhkan oleh pengadilan adalah talak raj'i. Dengan adanya ketentuan tentang talak ba in ini menyebabkan banyaknya perempuan yang dijatuhi talak $b a$ in dan secara langsung berimplikasi kepada tidak

9 Pasal 6 Undang-undang Mesir No. 20 Tahun 1920 dan Pasal 111 Undang-undang Suria mneyebutkan bahwa talak yang dijatuhkan oleh pengadilan adalah talak raj'i adanya nafkah bagi perempuan dalam masa iddah, dan hal ini terkesan tidak memberikan keadilan bagi perempuan. Berdasarkan permasalahan ini penulis mempertanyakan apakah ketentuan nafkah iddah talak bain dalam perundang-undangan di Indonesia memang tidak berpihak kepada keadilan gender? Atau sebaliknya perundang-undangan itu sudah sesuai dengan konsep keadilan gender yang diusung oleh penggiat gender dewasa ini.

\section{NAFKAH IDDAH TALAK BAIN DALAM PERSPEKTIF ULAMA MAZHAB}

Kata nafkah secara etimologi artinya biaya, belanja, pengeluaran uang. ${ }^{10}$ Sedangkan secara istilah syara' yang dimaksud nafkah adalah semua bentuk kebutuhan dan keperluan yang sesuai dengan keadaan dan tempat, seperti makanan, pakaian, rumah dan sebagainya. ${ }^{11}$ Dalam Kamus Besar Bahasa Indonesia kata nafkah berarti belanja hidup atau (uang) pendapatan. ${ }^{12}$ Bila seseorang dikatakan memberikan nafkah berarti harta yang dimilikinya menjadi berkurang karena sudah dikeluarkan untuk orang lain. Apabila dihubungkan dengan perkawinan maka nafkah berarti harta yang dikeluarkan suami untuk keperluan istrinya sehingga hartanya akan berkurang. Jadi nafkah istri berarti kewajiban suami terhadap istrinya dalam rentang perkawinan mereka. ${ }^{13}$

Kewajiban suami untuk menafkahi istrinya terdapat dalam al-Qur'an dan hadis. Hukum menafkahi istri, baik dalam bentuk kiswah (pakaian), makanan, dan belanja rumah

${ }^{10}$ Ahmad Warsono Munawwir, Kamus AlMunawwir Arab-Indonesia, (Surabaya: Pustaka Progresif, 1997), h.1449

${ }^{11}$ Sulaiman Rasyid, Fiqh Islam, (Bandung: Sinar Baru Algensindo [tth]), h. 421

${ }_{12}^{12}$ Departemen Pendidikan Nasional, Kamus Besar Bahasa Indonesia, (Jakarta: Pt.Gramedia Pustaka Utama, 2008), h.947

${ }^{13}$ Amir Syarifuddin, Hukum Perkawinan Islam di Indonesia, (Jakarta: Kencana, 2009), h.165 
tangga lainnya adalah wajib. Kewajiban itu bukan karena istri membutuhkannya, tetapi karena kewajiban itu muncul secara otomatis tanpa ada hubungannya dengan keadaan istri ${ }^{14}$.

Di antara ayat-ayat yang dapat dipedomani tentang kewajiban nafkah terhadap seseorang yang berada di bawah tanggungjawab suami antara lain terdapat dalam QS al-Baqarah [2]: 233, dan QS alThalaq [65]: 7. Sedangkan hadis yang menerangkan tentang kewajibab suami memberikan nafkah antara lain diriwayatkan oleh Muslim dari Jâbir ibn Abdullâh yang menegaskan suami wajib memberi rezki dan kiswah (pakaian) kepada istrinya secara patut. ${ }^{15}$ Ketentuan ini juga diperkuat oleh ijmak ulama, sebagaimana diiformasikan oleh ibn Qudâmah, kecuali si istri melakukan nusyuz.

Sebelum membahas tentang nafkah bagi perempuan yang beriddah, maka perlu dikemukakan tentang bentuk-bentuk talak dihubungkan dengan ada atau tidaknya hak rujuk bagi suami setelah perceraian.

Pertama; talak raj'i, yaitu talak kesatu atau kedua yang dijatuhkan oleh suami kepada istrinya, yang mana seorang suami, menurut Wahbah al-Zuhaylî, masih boleh rujuk kepada istrinya itu tanpa memerlukan akad yang baru selama istri masih beriddah. Hal itu terjadi setelah talak kesatu dan kedua yang tidak termasuk kategori ba in apabila telah sempurna rujuk sebelum habis masa iddah. Ketentuan ini didasarkan kepada QS al- Baqarah [2]: 228229. Ayat ini menjelaskan bahwa talak raji adalah talak kesatu atau talak kedua. Setelah suami menjatuhkan talak kesatu atau talak kedua, maka dia boleh rujuk kepada bekas istrinya sebelum habis masa iddahnya tanpa memerlukan akad yang baru dan tak perlu membayar mahar, tetapi bila habis masa

${ }^{14}$ Ibid

15 Muhammad ibn Ismâ'il al-Amîr al-Shan'ânî, Subul as-Salam Syarb Bulûgh al-Marâm, penerjemah, Ali Nur Medan dkk, jilid 3, (Jakarta: Darus Sunnah Press, 2013), h.175 iddahnya, maka diwajibkan untuk melakukan akad nikah lagi apabila suami ingin hidup bersama kembali dengan bekas istrinya. Akad nikah yang baru ini harus disertai dengan pembayaran mahar yang baru. ${ }^{16}$ Ayat ini juga menunjukkan bahwa istri-istri yang tertalak lebih boleh dirujuki kembali selama masa iddah, dengan syarat tidak ada niat dari suami untuk menyakiti istri setelah merujuknya.

Secara umum, akibat-akibat yang ditimbulkan oleh talak raj'i adalah; berkurangnya bilangan hak talak suami, ikatan perkawinan akan berakhir setelah habis masa iddah apabila suami tidak rujuk, dan suami dibolehkan untuk rujuk kembali dalam masa iddah istrinya. Ulama Syâfi'iyah dan Mâlikiyah menambahkan tentang keharaman bagi suami untuk melakukan hubungan suami istri dalam masa iddah sebelum ada kepastian rujuk, karena dengan terjadinya talak, maka seluruh bentuk hubungan suami istri terputus. Tetapi dalam pandangan Hanafiyyah dan Hanabilah, suami boleh watha' (menggauli) istrinya dalam masa iddah dan sikap inilah yang dianggap sebagai rujuk dari suami. ${ }^{17}$

Kedua, talak ba in, yaitu talak yang tidak memberi peluang rujuk bagi bekas suami terhadap bekas istrinya, dan untuk mengembalikan bekas istri ke dalam ikatan perkawinan dengan suami sebelumnya harus melaksanakan akad baru yang memenuhi syarat dan rukun perkawinan. ${ }^{18}$ Ketentuan rujuk ini juga menjadi sorotan dalam kajian gender, karena mayoritas ulama mengatakan bahwa persetujuan istri tidak diperlukan dalam menerima atau tidak menerima suaminya yang akan rujuk kembali. Bahkan ulama Hanafiyah dan Hanabilah menegaskan bahwa suami boleh merujuk istrinya dengan cara menyetubuhinya, tanpa perlu mengatakan kata-kata rujuk. Sedangkan ulama Mâlikiyah dan Syâfi'iyah mensyaratkan adanya kata-kata

\footnotetext{
${ }^{16}$ Amir Syarifuddin, Hukum..., h.221

17 Wahbah al- Zuhaylî, al-Figh..., h. 384

18 Abdul Rahman Ghazali, Figh..., h. 198-199
} 
rujuk dari suami, walaupun tidak harus mendengar persetujuan istri.

Talak ba in terbagi dua, yaitu bain sughrâ dan bain kubrâ. Talak ba`in sughrâ adalah talak yang dijatuhkan oleh suami terhadap istrinya dan konsekwensinya ia tidak dapat rujuk lagi, kecuali dengan aqad dan maskawin (mahar) baru, seperti telah disampaikan oleh Wahbah al-Zuhaylî. Lebih rinci penyebab talak ba in sughra itu ialah:

1. Talak sebelum berkumpul/sebelum istri digauli oleh suaminya. Dalam bentuk ini tidak memerlukan iddah. Oleh karena tidak ada masa iddah, maka tidak ada kesempatan rujuk, sebab rujuk hanya dilakukan dalam masa iddah ${ }^{19}$. Hal ini sesuai dengan QS AlAhzab [33]: 49.

2. Talak yang dilakukan dengan adanya tebusan dari istri atau khulu'. Hal ini dapat dipahami dari isyarat al-Qur`an dalam QS al- Baqarah [2]: 229.

3. Talak yang dijatuhkan sebab aib seperti cacat badan, atau salah seorang masuk penjara, atau talak disebabkan penganiayaan atau yang semacamnya.

4. Perceraian yang diputuskan oleh hakim di pengadilan atau yang disebut fasakh.

Adapun talak ba in kubrâ yaitu talak yang menghilangkan kepemilikan bekas suami terhadap bekas istri dan menghilangkan kehalalan bekas suami untuk kawin kembali dengan istrinya itu, kecuali bekas istrinya itu sudah menikah terlebih dahulu dengan laki-laki lain. Pernikahan kedua bekas istri itu tidak hanya sekedar aqad, tetapi juga telah melakukan hubungan kelamin (watha') dan kemudian sudah diceraikan pula oleh suami barunya itu dan telah habis pula masa iddahnya. ${ }^{20} \mathrm{Hal}$ ini disebutkan dalam QS alBaqarah [2]: 230 yang intinya membolehkan pernikahan kembali antara keduanya apabila mantan istri sudah diceraikan oleh suami keduanya atau perceraian karena kematian.

Ada dua kategori yang termasuk talak dalam bentuk ba in kubrâ ini, yaitu:

1. Istri yang telah ditalak tiga kali, atau talak tiga. Talak tiga dalam pengertian talak ba in itu adalah talak tiga yang diucapkan secara terpisah dalam kesempatan yang berbeda antara satu dengan lainnya diselingi oleh masa iddah. Inilah yang pendapat yang disepakati ulama.

2. Istri yang diceraikan oleh suaminya karena sebab li'an. Bedanya dengan kategori pertama adalah di mana bekas istri yang dili'an itu tidak boleh dinikahi lagi, meskipun sesudah diselingi oleh adanya muhallil menurut jumhur ulama.

Walaupun seorang istri sudah diceraikan oleh suaminya, ia masih mendapatkan hak-hak dari mantan suaminya selama berada dalam masa iddah, karena dalam masa itu dia tidak boleh melangsungkan perkawinan dengan laki- laki lain. Namun hak itu tidaklah sempurna sebagaimana yang berlaku pada saat mereka berada dalam hubungan perkawinan. Hak istri yang diterima tidak tergantung lamanya masa iddahnya, tetapi pada jenis perceraian yang dialaminya. ${ }^{21}$

Seorang istri yang diceraikan oleh suaminya dalam hubungannya dengan hak yang mesti diterimanya dapat dikelompokkan ke dalam tiga macam:

Pertama; istri yang dtalak raj'i, dia menerima hak penuh seperti pada saat masih dalam perkawinan, baik dalam bentuk makanan, kiswah (pakaian) dan tempat tinggal. ${ }^{22} \mathrm{Hal}$ ini disepakati oleh ulama. Kedua; istri yang ditalak ba in, baik ba in sughrâ atau ba in kubrâ dan dia dalam kondisi hamil, maka dalam hal ini ulama sepakat bahwa dia punya hak atas nafkah dan fasiltas tempat tinggal ${ }^{23}$ sebagaimana terdapat dalam al-Qur an dalam QS al-Thalaq [65]: 6. Menurut Wahbah al-

\footnotetext{
${ }^{19}$ Amir Syarifuddin, Hukum..., h. 221

${ }^{20}$ Wahbah al-Zuhayli
}

\footnotetext{
${ }^{21}$ Amir Syarifuddin, Hukum..., h. 322

22 Wahbah al-Zuhaylî, al-Fiqh..., h. 562

${ }^{23}$ Ibid
} 
Zuhayli, sebagaimana dikutip oleh Erwin Hikmatiar, ba in yang disebabkan oleh fasakh yang disebabkan oleh adanya aib juga tidak mendatangkan kewajiban bagi suami untuk menafkahi istrinya dalam masa iddah itu, karena dengan fasakh perkawinan sudah berakhir selama-lamanya. ${ }^{24}$

Bila ia tidak hamil, maka ulama berbeda pandangan. Pendapat pertama, di antaranya Umar dan anaknya, ibn Mas'ûd, ibn Abbâs, Imâm Mâlik, Imâm al-Syâfi'î dan Ahmad berpendapat bahwa perempuan itu berhak atas fasilitas tempat tinggal tetapi tidak berhak atas nafkah. ${ }^{25}$ Pendapat kedua dari Ali, ibn Abbâs, Jâbir, Atha', Thâwûs dan Dâwûd al-Zhâhirî dan pendapat yang umum di kalangan ulama Hanabilah, mereka mengatakan bahwa perempuan itu tidak mendapat nafkah dan juga tidak mendapat tempat tinggal. Alasannya ialah perkawinan telah putus sama sekali dan tidak ada pula kehamilan yang mesti dibiayai oleh suaminya. Pandangan ini diperkuat oleh atsar sahabi dari Fatimah bin Qais yang mengatakan "tidak ada nafkah bagimu kecuali bila kamu hamil”. Sedangkan pendapat ketiga dari Abû Hanîfah, al-Tsawrî, al-Hasan, ibn Syubrumah, yang berpendapat bahwa istri itu mempunyai hak atas nafkah dan fasiltas tempat tinggal.

Ketiga; hak yang didapatkan oleh istri yang kematian suami. Apabila istri hamil, maka ulama menyepakati dia mempunyai hak atas nafkah dan fasiltas tempat tinggal, namun jika terjadi sebaliknya (istri tidak hamil), maka di sini terjadi perbedaan pendapat ulama. Sebagian ulama di antaranya Imâm Mâlik, alSyâfî̀ dan Abû Hanîfah berpendapat dalam iddah kematian isteri berhak atas fasilitas tempat tinggal. Mereka mendasarkan pendapatnya dengan berpegang kepada

24 Erwin Hikmatiar, "Nafkah Iddah Pada Perkara Cerai Gugat (Livelihood Idda In Divorce Case Sues)", Mizan: Jurnal Ilmu Syariah, vol. 4, no. 1, 2016, h. 150

25 Amir Syarifuddin, Hukum..., h. 323 keumuman QS al-Baqarah [2]: 180 yang menyuruh istri ber-iddah di rumah suaminya. Sebagian ulama lainnya, antara lain Imâm Ahmad berpandangan bahwa dalam masa iddah kematian yang tidak hamil seorang isteri tidak berhak menerima nafkah dan fasilitas tempat tinggal, karena Allah hanya menentukan untuk yang kematian suami itu adalah peninggalan dalam bentuk harta warisan. ${ }^{26}$ Dari perbedaan pendapat ulama di atas, sepertinya pendapat Imâm Abû Hanîfah lebih menonjolkan keberpihakan kepada perempuan, di mana dalam setiap bentuk perceraian bekas suami harus tetap memberikan nafkah selama bekas istrinya menjalani iddah.

\section{KEADILAN GENDER}

Istilah gender mulai disosialisasikan oleh kelompok feminis di London sebagai konsep sosiologi sejak pertengahan kedua abad ke-20, tepatnya pada tahun 1997. Sejak itu para feminis cenderung tidak lagi menggunakan isuisu patrialkal atau sexist melainkan isu gender. Dalam bahasa Indonesia kata gender diartikan sama dengan seks, yakni jenis kelamin. Sebenarnya arti ini kurang tepat, tetapi sampai sekarang belum ditemukan kosa kata yang tepat untuk itu. ${ }^{27}$

Dalam Wikipedia dinyatakan bahwa gender dikaitkan dengan aspek hubungan sosial yang mengarah kepada perbedaan manusia dari segi seksual. ${ }^{28}$ Hilary M. Lips memahami istilah gender dengan budaya yang melekat pada laki-laki dan perempuan. Misalnya; perempuan dikenal dengan kelemahlembutannya, kecantikannya, emosional dan bersifat keibuan. Sedangkan laki-laki

${ }^{26}$ Ibid., h. 324

27 Siti Musdah Mulia, Islam dan Inspirasi Kesetaraan Gender, (Yogyakarta: Kibar Press, 2007), h. 55 28

http://www.wikipediaindonesia.com/pengertiangender.html Diakses tanggal 17 Juni 2018 
dipandang kuat, rasional dan perkasa. ${ }^{29}$ Hedi Shri Ahimsa Putra mengatakan bahwa ada beberapa pengertian dari gender ini, yaitu gender yang dipahami sebagai istilah baru dengan makna tertentu, gender sebagai fenomena dalam sosial dan budaya, gender sebagai kesadaran social masyarakat, gender sebagai persoalan sosial dan budaya, gender sebagai konsep untuk menganalisis, dan gender sebagai perspektif untuk melihat kenyataan yang terjadi. Secara umum, penelitian gender berangkat dari paradigma feminisme dengan dua teori yang diikuti; fungsionalisme struktural dan konflik. Fungsionalisme struktural itu bertitiktolak dari anggapan bahwa suatu tatanan masyarakat merupakan bagian yang saling melengkapi dan mempengaruhi. Teori ini berusaha mencari aspek-aspek yang mendasar dan berpengaruh dalam masyarakat. Teori fungsionalis dan sosial bersifat konservatif dan dapat dikaitkan dengan teori August Comte, Herbert Spencer, dan para ilmuwan lainnya. ${ }^{30}$

Di dalam Women's Studies Encyclopedia dinyatakan bahwa gender mrupakan konsep kultural yang mengupayakan membuat pembedaan, baik dalam hal peran, prilaku, mentalitas, dan karakter emosional laki-laki dan perempuan yang terjadi dalam masyarakat. Untuk konteks Indonesia, sejak sepuluh tahun terakhir ini perbincangan tentang gender sudah semakin berkembang, dan dari hasil pengamatan scientis, ternyata ada masih ada kerancuan masyarakat dalam memahami konsep gender. Ironisnya, kesalahan dalam memahami itu tidak hanya di kalangan orang awam saja, tetapi juga terjadi pada kalangan terpelajar dan pemuka agama. Hal ini karena istilah gender sering dipahami dengan seks atau perbedaan jenis kelamin, dan lebih fatal

${ }^{29}$ Mansour Fakih, Analisis Gender dan Transformasi Sosial, (Yogyakarta: Pustaka Pelajar, 1999), h. 8; Khariri, "Kesetaraan Gender Dalam Perspektif Islam: Reinterpretasi Fiqh Wanita", Yin Yang Jurnal Studi Gender dan Anak. Vol. 4. No. 1, 2009, h. 2

30 Ibid. h. 9 lagi gender dipahami dengan jenis kelamin perempuan saja, padahal gender mencakup kepada kedua jenis kelamin itu, yaitu laki-laki dan perempuan. ${ }^{31}$

Pada dasarnya, gender dan seks memiliki pengertian yang jauh berbeda. Secara umum gender dipakai untuk mengidentifikasi perbedaan peran laki-laki dan perempuan dalam konteks kehidupan sosial budayanya, sedangkan sex digunakan untuk membedakan laki-laki dan perempuan dari sisi anatomi biologinya. Istilah sex lebih banyak diarahkan kepada aspek biologi seseorang, sementara gender diarahkan kepada aspek sosial, budaya, dan psikologis. ${ }^{32}$

Adapun kata keadilan diartikan tidak sewenang- wenang, tidak memihak, dan tidak berat sebelah. Adil juga mengandung arti bahwa suatu tindakan harus didasarkan atas norma- norma yang objektif. Keadilan pada dasarnya adalah suatu konsep yang relatif, setiap orang tidak sama, adil menurut yang satu belum tentu adil bagi yang lainnya, kapan seseorang menegaskan bahwa ia melakukan suatu keadilan, hal itu tentunya harus relevan dengan ketertiban umum dimana suatu skala keadilan di akui ${ }^{33}$. Skala keadilan sangat bervariasi sesuai dengan tempat, setiap skala didefenisikan dan sepenuhnya ditentukan oleh masyarakat sesuai dengan ketertiban umum dari masyarakat tersebut.

Bagi kebanyakan orang keadilan merupakan prinsip umum, di mana setiap individu mestinya menerima apa yang pantas untuk mereka terima. Pada sebagian orang keadilan diistilahkan dengan legal justice (keadilan hukum) yang berpedoman kepada pelaksanaan hukum sesuai dengan prinsipprinsip yang telah ditetapkan dalam negara hukum. Ada pula yang mengistilahkan dengan
${ }^{31}$ Siti Musdah Mulia, Islam..., h. 55

${ }^{32}$ Heri Junaidi dan Abdul Hadi, "Gender..., h.

33 Agus Santoso, Hukum, Moral dan Keadilan, (Jakarta: Kencana Prenada Media Group, 2012), h.85 
sosial justice (keadilan sosial) yaitu konsepkonsep general mengenai keadilan sosial yang dimungkinkan tidak berbeda dengan konsep keadilan bagi individu atau keadilan secara umum.

Dalam Islam, adil berasal dari bahasa Arab yang dapat diartikan lurus (jujur) dan mengubah, menjauh, meninggalkan jalan yang salah untuk menuju jalan yang benar, sesuatu yang sama, menjadikannya sama atau seuatu yang sesuai, dan keseimbangan. Dalam Kamus Arab menyatakan bahwa "suatu hal yang ada dalam pikiran dalam keadaan keadaan jujur adalah keadilan, setiap yang tidak lurus atau tidak layak dianggap sebagai tidak adil". Ide tentang benar dan salah tersirat dalam istilah adl karena istilah ini sering digunakan dalam arti luas termasuk nilai- nilai dan agama ${ }^{34}$.

Menurut sistem Islam, apapun yang legal, lurus, dan sesuai dengan hukum Allah SWT adalah adil, konsep ini adalah sifat religius. Dalam pandangan Islam mengenai keseimbangan dunia yang diatur oleh ketetapan Allah SWT, keadilan adalah kebaikan dimana Allah SWT menyediakan hukum yang Dia sampaikan melalui AlQur`an. Prinsip- prinsip persamaan, pertengahan, proposional membawa keindahan di alam dan kebaikan bagi manusia. Menurut ajaran Islam, keadilan sudah mewakili tujuan mendasar dan tujuan akhir (ghayah) dari wahyu Allah SWT yang terdapat dalam alQur`an dan hadis. Ekspresi keadilan terlihat dalam tingkatan keadilan Allah terhadap makhluk-Nya dan keadilan manusia sesamanya.

Untuk memahami keadilan memang tergantung kepada budaya di mana seseorang tinggal, serta pemahaman dan tingkat kecerdasan masyarakatnya. Masalah keadilan tidak akan pernah habis diperbincangkan mulai sejak manusia ada sampai sekarang. Pemahaman mengenai keadilan itu tergantung

$$
{ }^{34} \text { Ibid., h. } 86
$$

kepada apa yang dituntut oleh manusia pada saat ia ada. Tuntutan keadilan pada masyarakat yang masih tradisional tentu tidak sama dengan tuntutan keadilan pada masyarakat yang sudah modern, sehingga tidak dimungkinkan adanya norma keadilan yang sifatnya berlaku secara mendunia. ${ }^{35}$

Keadilan dalam konsep gender sendiri dikenalkan oleh ilmuwan dalam ilmu sosial sebagai upaya menjelaskan adanya perbedaan antara perempuan dan laki-laki, yang semua itu merupakan hasil dari budaya yang dipahami diperkenalkan sejak kecil. Pembedaan ini menjadi penting, karena sebelumnya seringkali terjadi pencampur-adukan antara ciri-ciri manusia yang bersifat alami (kodrati) dan yang bersifat bukan alami (gender). Perbedaan keberperanan gender ini sangat membantu untuk mengubah gaya berpikir tentang pembagian peran yang sebelum ini sudah melekat pada diri seorang perempuan dan lakilaki. Perubahan cara pikir ini juga untuk membuat gambaran relasi (hubungan) gender yang dinamis dan tepat serta sesuai dengan realita yang hidup di tengah masyarakat. ${ }^{36}$

Adapun konsep keadilan dalam perspektif gender merupakan suatu kondisi yang berkeadilan untuk laki-laki dan perempuan dengan melewati proses budaya dan kebijakan yang dapat menghilangkan penghalang-penghalang keberperanan bagi laki-laki dan perempuan. Pengertian dari USAID menyatakan bahwa keadilan gender adalah suatu proses yang dilewati untuk menjadi fair, baik pada laki-laki maupun perempuan. Untuk memastikan itu, harus ada suatu ukuran yang dipakai untuk mengkompensasi kerugian secara histori ataupun sosial yang menghalagi laki-laki dan perempuan dari berlakunya suatu tahapan

${ }^{35}$ Maryati Bachtiar, "Hukum Waris Islam Dipandang Dari Perspektif Hukum Berkeadilan Gender", Jurnal Ilmu Hukum, vol. 3, no.1, 2012, h. 4

36 Herien Puspitawati, Konsep, Teori dan Analisis Gender, (Bogor: IPB Press,2012), h. 1 
permainan. Strategi berkeadilan gender itu ujung-ujungnya dipakai untuk meningkatkan/menumbuhkan semangat kesetaraan gender. Dengan demikian keadilan hanyalah cara yang ditawarkan, sedangkan kesetaraan adalah hasilnya. ${ }^{37}$

$$
\text { Dapat dipahami bahwa konsep }
$$

keadilan dan kesetaraaan gender ialah suatu kondisi di mana pada saat itu peran dan siklus sosial laki-laki dan perempuan dapat disetarakan, diseimbangkan, dan berjalan secara harmonis. Kondisi ini bisa diwujudkan bila ada perlakuan adil antara laki-laki dan perempuan. Penerapan keadilan dan kesetaraan gender itu tentunya mesti mempertimbangkan atau menyesuaikan dengan situasi dan konteks yang ada. Kondisi situasional dari sebuah konteks menunjukkan bahwa penerapan kesetaraan gender tidak dapat berlaku secara sama di semua strata masyarakat. Kesetaraan manusia juga bermakna bahwa sebagai makhluk Tuhan manusia mempunyai tingkatan yang sama. Tingkatan yang sama itu berasal dari pandangan bahwa tanpa dibedakan, manusia diciptakan dengan kedudukan yang sejajar, yaitu sebagai makhluk paling mulia dan lebih tinggi derajatnya dibandingkan dengan makhluk lainnya. ${ }^{38}$

Diskriminasi gender dan ketidakadilan yang ada di sekitarnya merupakan kesenjangan dan ketidakadilan disebabkan struktur sosial yang melingkupinya. Akibatnya laki-laki dan perempuan dikorbankan dengan adanya struktur tersebut. Keyakinan yang ditanamkan sepanjang waktu dari dulu sampai sekarang menyebabkan ketidakadilan gender tersebut. Hal ini tidak hanya menimpa perempuan saja tetapi juga bagi laki-laki. Secara keseluruhan, ketidakadilan gender ini dalam bebrgai bidang kehidupan lebih mengarah kepada kaum perempuan, dan hal ini pada akhirnya juga

\footnotetext{
${ }^{37}$ Ibid. h. 5

${ }^{38}$ Mansour Fakih, Analisis..., h. 11
}

berdampak pula terhadap laki-laki. ${ }^{39}$

\section{ANALISIS KEADILAN GENDER DALAM NAFKAH IDDAH TALAK BA IN}

Pada dasarnya talak merupakan perbuatan hukum yang dapat menimbulkan akibat hukum berupa hak dan kewajiban antara mantan suami dan mantan istri. Salah satu hak dan juga kewajiban suami dan istri pasca terjadinya talak dinyatakan di dalam Pasal 149 (b) KHI yang menyatakan bahwa apabila perkawinan putus disebabkan talak, maka mantan suami diwajibkan memberikan nafkah, maskan (tempat tinggal) dan kiswah (pakaian) kepada mantan istrinya selama dalam masa iddah, kecuali mantan istri dijatuhi talak ba' in atau nusyuz (durhaka) dan dalam kondisi tidak hamil. ${ }^{40}$

Berdasarkan pasal di atas, maka menurut penulis tampak bahwa KHI pada dasarnya membebankan kewajiban kepada suami untuk memberi nafkah iddah hanya kepada bekas istri yang tidak nusyuz dan tidak di jatuhi talak ba in. Artinya, secara otomatis jika istri menggugat cerai kepada suami, maka suami tidak memiliki kewajiban untuk memenuhi nafkah, maskan, dan kiswah jika terjadi perceraian karena istri yang menggugat cerai akan dijatuhi talak ba in.

Namun pada Pasal 152 KHI dinyatakan bahwa mantan istri tetap mempunyai hak untuk mendapatkan nafkah iddah dari mantan suaminya selama ia tidak nusyuz. $^{41}$ Itu artinya hanya bekas istri yang nusyuz yang tidak mendapatkan hak nafkah iddah sedangkan mantan istri yang dijatuhi talak ba in tidak disebutkan dan hak yang diperoleh hanya sebatas nafkah iddah tidak disertai dengan maskan dan kiswah. Dari

${ }^{39}$ Orinton Purba, Konsep dan Teori Gender dalam https://gendernews88.wordpress.com Diakses Tanggal 21 Juni 2018 (KHI)

${ }^{40}$ Pasal 149 huruf b Kompilasi Hukum Islam

${ }^{41}$ Pasal 152 Kompilasi Hukum Islam (KHI) 
gambaran di atas terlihat seolah KHI tidak konsisten dalam mengatur sesuatu yang menjadi hak bagi istri yang ditalak ba in .

Sekilas aturan hukum dalam pasal 149 (b) KHI terkesan tidak adil karena seorang mantan istri ketika diceraikan oleh suaminya tidak dinafkahi (selama masa iddah) sedangkan dia tinggal sendiri atau bersama anak-anaknya dan terikat dengan ketentuan iddah. Kondisi ini menggambarkan betapa teraniayanya kaum perempuan dalam masa iddah, tidak dinafkahi tetapi harus menunggu habisnya masa iddah. Oleh karena itu dalam rangka memberikan perlindungan kepada perempuan, maka konsep nafkah pasca talak ba in harus dianalisa lebih lanjut dengan mempertimbangkan perspektif fiqh dan juga keadilan gender, khususnya kepada kaum perempuan.

Jika dilihat dari perspektif fiqh, maka dapat dilihat bahwasanya para fuqaha' sendiri berbeda pendapat mengenai pemberian nafkah iddah pada talak båin. Ulama Hanabilah, Zhâhiriyah, Ishâq dan Abû Tsaur berpandangan bahwa istri yang tertalak ba in tidak mendapatkan hak nafkah dan fasilitas tempat tinggal sekalipun hamil. Alasan mereka, nafkah dan fasilitas tempat tinggal diwajibkan sebagai imbalan rujuk bagi suami, sedangkan dalam talak ba in suami tidak memiliki hak rujuk, oleh karenanya tidak ada nafkah dan fasilitas tempat tinggal. Hal ini sebagaimana hadis dari riwayat Fatimah binti Qais yang pernah ditalak suaminya yang ketiga kalinya, bahwa Nabi tidak menjadikan nafkah dan fasilitas tempat tinggal baginya. Bagi wanita yang terputus haid hendaklah ber-iddah sekehendaknya. ${ }^{42}$

Ulama Hanafiyah berpendapat perempuan yang tertalak ba in berhak atas nafkah dan fasilitas tempat tinggal secara bersama, kecuali apabila perempuan tersebut ber-iddah karena perceraian yang disebabkan oleh pelanggaran istri, seperti istri murtad

\footnotetext{
${ }^{42}$ Wahbah al-Zuhaylî, al-Figh..., h. 657
}

setelah bercampur atau tindakan istri menodai kehormatan mertua seperti orang tua suami dan saudara-saudaranya, istri hanya berhak tempat tinggal tetapi tidak mempunyai hak nafkah. ${ }^{43}$ Adapun alasan dari pendapat ini, ulama Hanafiyah berpegang pada QS alThalaq [65]: 6.

Adapun pendapat ulama Mâlikiyah, Syâfi'iyah dan Jumhur Ulama Salaf berpedapat bahwa istri berhak atas tempat tinggal, baik hamil maupun tidak, dan berhak nafkah jika hamil. Dalilnya sebagai berikut:

1. Ayat "berikan tempat tinggal mereka....." (QS al-Thalaq [65]: 6); Allah mewajibkan memberikan fasilitas tempat tinggal kepada mereka tanpa ada kelebihan dan menggantungkan kewajiban nafkah pada istri hamil. Nafkah wajib karena hamil dan tidak wajib karena tidak hamil.

2. Tidak adanya hubungan antara nafkah dengan tempat tinggal, tidak adanya pendapat seperti ulama Hanabilah dan seperti pendapat ulama Hanafiyah. Tempat tinggal yang wajib bagi istri yang tercerai agar dapat menunggu yang dituntut, dengan demikian tempat tinggal wajib bagi semua wanita yang ber-iddah. Sedangkan nafkah wajib baginya karena dua sebab yakni suami masih berhak kembali kepada istri pada talak raj'i serta menghidupi anak bagi istri yang hamil. ${ }^{44}$

Pendapat ulama Hanafiyah juga dikuatkan oleh riwayat dari Umar bin Khattâb ra, Umar bin 'Abd al-'Azîz dan Sufyân Ats Tsaurî. Mereka berpendapat bahwa bekas istri pada talak ba in berhak mendapatkan nafkah dan rumah. Mereka mengambil dalil kepada firman Allah QS al-Thalaq [65]: 6 : "....tempatkanlah mereka (isteri) di mana kamu berada (bertempat tinggal) menurut kemampuanmu". Ayat ini menurut mereka menerangkan

${ }^{43}$ Wahbah al-Zuhaylî, al-Fiqh..., h. 657

${ }^{44}$ Abdul Aziz Azzam dan Abdul Wahhab Sayyed Hawwas, Fiqh Munakahat (Khitbah, Nikah dan Talak), (Jakarta: Amzah, 2009), h. 335 
wajibnya memberi tempat tinggal. Jika secara hukum wajib memberikan tempat tinggal, maka dengan sendirinya wajib memberikan nafkah, karena adanya kewajiban memberi tempat tinggal dalam talak perempuan hamil dan karena sebagai istri itu sendiri. ${ }^{45}$ Berbeda dengan itu, ulama Hanabilah, Zhâhiriyah, Ishâq dan Abû Tsaur berpendapat bahwa ia tidak mempunyai hak untuk mendapatkan nafkah dan fasilitas tempat tinggal sekalipun hamil dengan dasar hadis dari Fatimah binti Qais. Umar dan Aisyah pernah menolak hadis Fatimah binti Qais yang ia sampaikan di atas. Kata Umar: "Kami tidak meninggalkan alQur'an dan Sunnah Nabi kami karena keterangan seorang perempuan. Kami tidak tahu bisa saja ia hafal atau telah lupa". ${ }^{46}$

Berdasarkan beberapa pendapat ulama sebagaimana telah dikemukakan di atas, maka dapat dipahami bahwa ketentuan dalam KHI yang mengatur bahwa tidak ada nafkah iddah bagi istri yang tertalak ba in sejalan dengan pendapat ulama-ulama dari kalangan Mâlikiyah, Syâfi'iyah dan Jumhur ulama Salaf yang berpendapat bahwa istri berhak atas fasilitas tempat tinggal, baik hamil maupun tidak, dan berhak nafkah jika hamil.

Meskipun KHI lebih menitikberatkan aturan mengenai nafkah pada pada talak ba in ini kepada pendapat ulama Mâlikiyah, Syâfi'iyah dan Jumhur ulama Salaf yang pada umumnya mengatakan bahwa istri yang tertalak ba'in tidak mendapatkan hak nafkah iddah, namun penulis kurang sependapat dengan itu dan lebih cenderung kepada pendapat ulama Hanafiyah yang mengatakan bahwa istri yang ditalak ba in tetap mendapatkan hak nafkah dan fasilitas tempat tinggal sama dengan perempuan yang tertalak raj'i berdasarkan zahir QS al-Thalaq [65]: 6. Hanafiyah berpendapat bahwa dalam QS al-

${ }^{45}$ Sayyid Sabiq, Figh Sunnah, jilid 7, diterjemahkan Muhammad Thalib, "Fikih Sunnah, (Bandung: Al Ma'arif, 1987), h. 98

${ }^{46}$ Ibid., h. 98
Thalaq [65]: 6 secara zahir terdapat perintah tentang wajibnya memberikan tempat tinggal yaitu pada kalimat askinûhunna (berikanlah mereka tempat tinggal) dan isteri yang tertalak itu harus menghabiskan masa tunggunya (iddah) di rumah suaminya. Istri yang ditalak ba in tersebut akan terkurung di rumah suaminya sebab suaminya masih mempunyai hak terhadapnya berupa kepastian ada atau tidaknya pembuahan dalam rahim sehingga wajar jika perempuan tersebut berhak mendapatkan nafkahnya. Adapun mengenai nafkah dalam ayat tersebut yang dikaitkan dengan kehamilan, hal itu dikarenakan iddah hamil adalah iddah yang terlama sehingga perlu ditegaskan, sedangkan untuk masa iddah yang pendek, sudah tercakup di dalamnya. Nafkah tersebut dianggap sebagai hutang sejak suami menjatuhkan talaknya, dan hutang ini tidak bisa lunas, kecuali dengan membayarnya atau direlakan oleh istri. ${ }^{47}$ Pendapat ini juga pernah disampaikan oleh Umar bin Khattab, Ibnu Mas'ûd, sahabat dan tabi'in lainnya dan al-Tsawrî. ${ }^{48}$

Adapun alasan penulis lebih cenderung kepada pendapat yang menetapkan tetap adanya nafkah iddah bagi perempuan yang tertalak ba in adalah karena terdapatnya mashlahat-mashlahat yang perlu dilindungi bagi wanita yang tertalak raj'i dan ditetapkan mendapatkan nafkah iddah tidak berbeda dengan mashlahat-mashlahat yang perlu dijaga bagi perempuan yang tertalak ba in, di mana keduanya sama-sama terkungkung dalam kewajiban masa iddah dan sudah sewajarnya mereka mendapatkan hak nafkahnya. Dilihat dari sisi maslahah ini, maka pada dasarnya seorang mantan istri selama dalam masa iddah wajib diberikan nafkah karena tanpa adanya nafkah maka mantan istri tersebut akan berada dalam kondisi kekurangan disebabkan tidak adanya nafkah, sedang ia wajib tinggal di

${ }^{47}$ Ibid., h. 216

${ }^{48}$ Wahbah Al-Zuhaylî, al-Figh..., h. 673 
kediaman suaminya dan tidak dapat keluar untuk mencari penghidupan.

Jiwa merupakan salah satu dharuriyat al-khams yang wajib dipelihara. Untuk mencapai tujuan ini ajaran Islam tidak membolehkan adanya pembunuhan, penganiayaan, dan perbuatan-perbuatan lainnya yang berpotensi mengancam jiwa. Jika aturan yang melarang perbuatan tersebut tetap dikerjakan, maka hukum Islam sudah menyiapkan sanksi fisik yang sangat berat, seperti diqishasnya orang yang melakukan pembunuhan dan penganiayaan, serta sanksi yang serius untuk mereka yang mencoba menghilangkan nyawanya sendiri. Aturanaturan ini semua dibuat untuk melindungi eksistensi jiwa dalam kehidupan di dunia ini. ${ }^{49}$

Wajibnya memelihara jiwa telah dimulai sejak di dalam rahim yakni dengan adanya syari'at nikah dan pengharaman zina. ${ }^{50}$ Perlindungan jiwa tersebut berlanjut dengan kewajiban orang tua mengurus anak tersebut sejak lahir sampai mandiri bagi laki-laki dan sampai menikah bagi perempuan. Bagi seorang perempuan, setelah menikah maka kepengurusannya beralih kepada suami dan setelah terjadinya perceraian semestinya suami belum bebas dari tanggung jawab sampai habisnya masa iddah.

Hal ini sejalan dengan zhahir QS alThalaq [65]: 1 yang mewajibkan mantan istri tetap berada di rumah selama menjalani masa iddahnya dan QS al-Thalaq [65]: 6 yang mewajibkan mantan suami menyediakan tempat tinggal bagi mantan istri. Menurut penulis, adalah tidak logis ketika seorang perempuan yang terkurung di rumah mantan suami tanpa ada yang menafkahinya. Logika Hanafiyah tentang kewajiban nafkah yang dikaitkan dengan kehamilan dikarenakan masa

\footnotetext{
${ }^{49}$ Busyro, Dasar-dasar Filosofis Hukum Islam, (Ponorogo: Wadegrup Publishing, 2017). h. 144

${ }^{50}$ Yûsuf Hâmid al-'Âlim, al-Maqâshid al-'Ammah li al-Syarìah al-Islâmiyah, (Riyâdh, Dâr-'Alamiyah li alKutub al-Islâmi, 1994), h. 272
}

iddah hamil adalah yang terlama juga sangat tepat, artinya masa iddah yang lebih pendek dari itu telah tercakup dalam konteks tersebut.

Adapun mengenai hadis Fathîmah bint Qais yang menyebutkan bahwa istri yang dijatuhi talak ba in tidak mendapatkan hak nafkah dan fasilitas tempat tinggal bukan hadis mutawatir. ${ }^{51}$ Akan tetapi hanya merupakan hadis ahad yang kedudukannya sebagai dalil masih diperdebatkan. ${ }^{52}$ Dalam konteks ini hanya Hanâbilah dan Zhâhiriyah yang mengamalkan hadis tersebut sedangkan Jumhur ulama yakni Hanafiyah, Mâlikiyah, dan Syâfi'iyah tidak mengamalkan hadis tersebut. Di samping itu hadis Fathîmah bint Qais ini ditolak oleh Umar bin Khattab. Di sisi lain, sebagaimana disebutkan oleh al-Jashâs patut diduga kebijakan Rasulullah SAW menggugurkan hak Fathîmah bint Qais dikarenakan dia terlalu banyak bicara dengan keluarga suaminya sehingga dia disuruh pindah dan perpindahan tersebut dapat dianggap nusyuz dan nusyuz menggugurkan nafkah dan tempat tinggal. ${ }^{53}$

Aturan hukum dalam Pasal 149 (b) KHI sepanjang mengenai nafkah iddah talak ba in menurut penulis kurang tepat untuk diterapkan dan tidak memenuhi rasa keadilan gender, sebab dalam keadaan ini mantan istri dikategorikan tidak mampu menafkahi dirinya selama menjalani masa iddah karena harus terikat dengan masa tunggunya yang cukup lama. Apalagi selama masa perkawinannya ia hanya mengharapkan nafkah dari suaminya. Dengan dikesampingkannya ketentuan pasal tersebut maka penafsiran pasal 41 huruf c Undang-undang No. 1/1974 meliputi talak raj'i dan talak ba'in. Hal ini juga telah ditegaskan dalam buku II Mahkamah Agung tentang Pedoman Pelaksanaan tugas dan administrasi Peradilan Agama sekalipun tidak

\footnotetext{
51 Wahbah al-Zuhaylî, al-Figh..., h.151

52 Ibid

${ }^{53}$ Abû Bakar al-Jashâsh, Abkâm al-Qur'ân, (Beirut: Dâr al-Ihyâ' al-Turâts al-'Arabi, 1992), h. 357
} 
ada kata tegas untuk mengenyampingkan ketentuan pasal 149 (b).

Ketentuan dalam pasal 149 (b) ini, jika dilihat dari perspektif keadilan gender, maka menurut penulis terlihat tidak adil atau berat sebelah di mana nafkah iddah hanya diberikan kepada mantan istri jika ia ditalak raj'i dalam artian suami yang menjatuhkan talak kepada istri, sedangkan dalam keadaan istri yang menggugat cerai suami dan diputus pengadilan dengan status talak bain, maka istri tidak berhak mendapat nafkah iddah. Hal ini terlihat kurang adil sebab jika suami yang menjatuhkan talak maka baru istri mendapat nafkah iddah sedangkan jika istri yang menggugat cerai maka haknya mendapat nafkah iddah menjadi hilang.

Dalam perspektif kesetaraan gender, seharusnya laki-laki dan perempuan diberikan status yang seimbang dan setara dan memiliki hak yang sama untuk mewujudkan hak-hak asasi mereka. Kesetaraan gender memberikan peluang yang seimbang/sebanding secara sosial baik pada laki-laki maupun perempuan untuk menikmati hak-haknya sebagai manusia. ${ }^{54}$ Dalam hal ini, jika dikaitkan dengan ketentuan mengenai nafkah iddah bagi istri yang tertalak ba'in sebagaimana yang dinyatakan dalam pasal 149 (b) KHI maka terlihat bahwa ada ketidaksetaraan antara lakilaki dan perempuan di mana saat perempuan yang mengajukan gugatan cerai, maka ia kehilangan haknya untuk mendapatkan nafkah iddah, padahal secara jelas nafkah iddah merupakan hak bagi perempuan selama masa iddahnya.

Jika dilihat secara eksplisit, maka terdapat kesan bahwa KHI menetapkan aturan yang berat sebelah, apalagi mengingat terkadang seorang perempuan atau isteri merupakan sosok yang double burden (melakukan peran ganda) dalam rumah tangga. Peran ganda adalah adanya dua beban pekerjaan bahkan lebih yang harus diemban

\footnotetext{
${ }^{54}$ Herien Puspitawati, Konsep..., h. 5
}

oleh perempuan. Perempuan sering kali tidak punya pilihan lain kecuali menjalani peran ganda tersebut demi kelangsungan hidupnya. ${ }^{55}$ Sehingga, menurut penulis saat ia bercerai dari suaminya, dan berada dalam masa iddah, sudah seharusnya ia mendapatkan nafkah selama menjalani masa iddah. Hal ini mengingat begitu banyaknya tugas dan tanggung jawab yang telah ia emban selama membina rumah tangga, dan sudah seharusnya hak yang sebenarnya memang menjadi haknya diberikan oleh mantan suaminya.

Ketentuan Kompilasi Hukum Islam (KHI) dalam Pasal 149 (b) yang menyatakan bahwa nafkah iddah diberikan kepada mantan istri selama menjalani masa iddah kecuali istri yang tertalak ba'in atau nusyuz, menurut penulis secara eksplisit memang memberi kesan bahwa ada ketidakadilan atau ketidaksetaraan hak yang diterima antara lakilaki dan perempuan yang dalam hal ini antara suami dan istri. Aturan ini terkesan diskriminatif dalam memposisikan perempuan selaku pihak penggugat. Padahal dalam hal ini perempuan merupakan pihak yang paling harus dilindungi kemashlahatannya mengingat pasca dijatuhi talak ba in perempuan harus terkungkung dalam masa iddah dan tidak dapat mencari penghidupan atau melakukan pernikahan dengan orang lain yang dapat menjamin kehidupannya.

Berdasarkan analisa-analisa yang telah dilakukan terhadap pasal 149 (b) KHI di atas dengan melihat dari berbagai sudut pandang teori gender yang ada, maka dapat disimpulkan bahwa aturan itu belum memenuhi rasa keadilan dan terkesan diskriminatif terhadap perempuan. Selain itu aturan ini juga belum sejalan dengan cita-cita berkeadilan dalam kesetaraan gender yang diharapkan. Adapun teori keadilan gender yang paling ideal dan diharapkan dapat diterapkan dalam KHI

55 Nur M. Kasim, "Perspektif Islam Tentang Gender”, Jurnal Inovasi, Vol 9, No. 2, Juni 2012, hlm. 4 
adalah teori kedilan gender feminisme liberal di mana menurut teori ini laki-laki dan perempuan seharusnya memiliki hak yang seimbang dalam beberapa hal yang tentunya tidak menghilangkan sifat kodrati dari keduanya.

Mary Wollstonecarft, salah satu tokoh pejuang gender ternama pada tahun 1789, menyatakan bahwa setiap orang, baik laki-laki maupun perempuan, sama-sama memiliki hak yang sama dan seharusnya tidak dibolehkan adanya tindakan yang menindas antara satu pihak dengan pihak lainnya. Menurutnya, kapasitas rasionalitas yang dimiliki laki-laki setara dengan perempuan. Hal ini menyebabkan mereka mempunyai peluang yang sama pula dalam memutuskan sesuatu dan menentukan pilihannya. ${ }^{56}$

Berdasarkan konsep kesetaraan dan keadilan gender, maka dapat dilihat bahwa pasal 149 (b) belum mengakomodir adanya kesempatan bagi para perempuan untuk memutuskan nasibnya sendiri dan terbebas dari segala bentuk penindasan. Dengan adanya aturan ini, pihak perempuan tidak dapat memutuskan jalan hidup terbaik yang ingin ia pilih, apakah tetap bertahan dengan rumah tangga yang telah ia bina selama ini, atau memilih untuk bercerai jika dirasa memang tidak bisa lagi mempertahankan rumah tangga dan memilih untuk hidup mandiri dan mencari penghidupan sendiri.

Pada kondisi-kondisi di mana mantan istri yang tertalak ba in merupakan perempuan yang tidak memiliki sumber penghidupan lain kecuali bergantung pada suaminya, maka setelah istri tersebut dijatuhi tertalak ba in namun tidak memiliki tempat untuk hidup selain di rumah mantan suaminya dan tidak punya sumber penghidupan lain selain bergantung pada suaminya, maka dengan diterapkannya pasal 149 (b), akan membahayakan kehidupan perempuan

${ }^{56}$ Nasarudin Umar, Argumen, ..., h. 57 tersebut. Hal ini tentunya tidak adil bagi pihak perempuan karena ia diikat dengan kewajiban masa iddah, sementara haknya untuk mendapatkan nafkah dihilangkan dari dirinya.

Berdasarkan beberapa uraian di atas, maka dapat dipahami, dengan diterapkannya Pasal 149 (b) KHI yang menetapkan bahwa istri yang tertalak ba in tidak mendapatkan hak nafkah iddah, maka tampak bahwa jika dilihat dari sudut pandang gender, aturan-aturan yang ditetapkan oleh Kompilasi Hukum Islam ini pada dasarnya belum sejalan dengan konsep kesetaraan dan keadilan gender, di mana dalam konsep kesetaraan dan keadilan gender antara laki-laki dan perempuan memiliki hak yang setara, termasuk berhak untuk diperlakukan secara adil di muka hukum. Apalagi pada kasus mantan istri yang benar-benar tidak mampu menghidupi dirinya sendiri pasca tertalak ba in sebab memang tidak memiliki pekerjaan selain menjadi ibu rumah tangga, sementara suami terbukti memiliki kemampuan untuk memberikan nafkah iddah, maka pada kasus ini perundang-undangan di Indonesia termasuk KHI seharusnya tidak menutup kemungkinan untuk membebankan mantan suami untuk memberikan nafkah iddah kepada mantan istri selama menjalani masa iddahnya.

Dengan melihat kepada pendapat ulama mazhab, maka pemikiran hukum Imam Abû Hanîfah sepertinya sangat berpihak kepada keadilan gender, dalam hal ini pemenuhan hak perempuan ketika ia diwajibkan untuk beriddah dan tinggal di rumah suaminya ketika masa iddah tersebut. Imam Abû Hanîfah telah mendahului pemikiran gender yang ada sekarang dan berpeluang diterapkan dalam pembaruan hukum perkawinan di Indonesia. Pemikiran kesetaraan gender ini dalam pemikiran hukum Imam Abû Hanîfah ini tidak hanya berhubungan dengan masalah nafkah iddah talak ba in ini, tetapi juga mencakup pemberian hak kepada perempuan untuk menjadi hakim, menjadi wali untuk dirinya sendiri dan orang 
lain, dan sudah menjadikan perempuan sebagai subjek hukum yang sama dengan laki-laki pada berbagai persoalan. ${ }^{57}$

\section{KESIMPULAN}

Keadilan dan kesetaraan gender dalam hubungannya dengan nafkah iddah bagi istri yang tertalak bain, sebagaimana terdapat dalam hukum perkawinan bagi umat Islam di Indonesia, belum dapat dikategorikan sebagai produk hukum yang berkeadilan gender. Walaupun hukum perkawinan tersebut telah mengadopsi pendapat Jumhur ulama, tetapi sisi keadilan yang diharapkan didapatkan oleh perempuan dalam mengakhiri perkawinannya belum terwujud. Hal ini karena mereka mempunyai kewajiban menjalankan iddah setelah bercerai dan menempati rumah suaminya dalam masa iddah tersebut, baik dalam talak raj'i maupun talak bain. Keharusan menjalani iddah di rumah suaminya tentu harus diimbangi dengan hak nafkah yang mesti mereka terima selama masa menunggu tersebut. Hak nafkah tersebut tetap diberikan kepada perempuan, sebagaimana pemikiran hukum Imâm Abû Hanîfah karena itulah keadilan gender yang mesti mereka dapatkan dengan kewajiban beriddah yang dibebankan kepadanya. Pembaruan hukum perkawinan Islam di Indonesia sudah seharusnya memperhatikan pemikiran hukum Imâm Abû Hanîfah ini untuk menjamin adanya keadilan bagi perempuan yang bercerai dengan suaminya.

\footnotetext{
57 Busyro, "Pengarusutamaan Gender Dalam Pemikiran Hukum Imam Abu Hanifah dan Relevansinya Dengan Pembaharuan Hukum Islam", AlHurriyah Jurnal Hukum Islam, vol. 1, no. 1, 2016, h. 15-26
} 


\section{DAFTAR KEPUSTAKAAN}

'Âlim, Yûsuf Hâmid al-, al-Maqâshid al-'Ammah li al-Syarî'ah al-Islâmiyah. Riyâdh, Dâr-'Alamiyah li alKutub al-Islâmi, 1994

Azzam, Abdul Aziz dan Abdul Wahhab Sayyed Hawwas, Fiqh Munakahat (Khitbah, Nikah dan Talak). Jakarta: Amzah, 2009

Bachtiar, Maryati, "Hukum Waris Islam Dipandang Dari Perspektif Hukum Berkeadilan Gender", Jurnal Ilmu Hukum, vol. 3, no.1, 2012

Busyro, "Pengarusutamaan Gender Dalam Pemikiran Hukum Imam Abu Hanifah dan Relevansinya Dengan Pembaharuan Hukum Islam”, Al-Hurriyah Jurnal Hukum Islam, vol. 1, no. 1, 2016

Busyro, Dasar-dasar Filosofis Hukum Islam. Ponorogo: Wadegrup Publishing, 2017

Dardiri, Ahmad ibn Muhammad al-, Syarh al-Shaghir, juz 2. t.tp, t.p, [tth]

Departemen Pendidikan Nasional, Kamus Besar Bahasa Indonesia. Jakarta: PT Gramedia Pustaka Utama, 2008

Fakih, Mansour, Analisis Gender dan Transformasi Sosial. Yogyakarta: Pustaka Pelajar, 1999

Ghozali, Abdul Rahman, Fiqh Munakahat. Jakarta: Kencana, 2010

Helmi, Muhammad, “Konsep Keadilan Dalam Filsafat Hukum Dan Filsafat Hukum Islam”, Jumal Mazahib, vol. 14, no. 2, 2015

Hikmatiar, Erwin, "Nafkah Iddah Pada Perkara Cerai Gugat (Livelihood Idda In Divorce Case Sues)", Mizan: Jurnal Ilmu Syariah, vol. 4, no. 1, 2016

http://www.wikipediaindonesia.com/pengertian-gender.html Diakses tanggal 17 Juni 2018

Jashâsh, Abû Bakar al-, Abkâm al-Qur ân. Beirut: Dâr al-Ihyâ’ al-Turâts al-'Arabi, 1992

Junaidi, Heri dan Abdul Hadi, "Gender dan Feminisme dalam Islam”. Jurnal Muwazah. Vol 2. No.2, 2010

Kasânî, Abû Bakar ibn Mas'ûd al-, al-Badâ’' al-Shanâ'i', juz 4. Beirut: Dâr al-Kutub al-Ilmiyah, 2010

Kasim, Nur M., “Perspektif Islam Tentang Gender”, Jurnal Inovasi. Vol 9. No.2, 2012

Khariri, "Kesetaraan Gender Dalam Perspektif Islam: Reinterpretasi Fiqh Wanita", Yin Yang Jumal Studi Gender dan Anak. Vol. 4. No. 1, 2009

Kompilasi Hukum Islam Tahun 1991

Mulia, Siti Musdah, Islam dan Inspirasi Kesetaraan Gender. Yogyakarta: Kibar Press, 2007

Munawwir, Ahmad Warsono, Kamus Al-Munawwir Arab-Indonesia. Surabaya: Pustaka Progresif, 1997

Purba, Orinton, Konsep dan Teori Gender dalam https://gendernews88.wordpress.com Diakses Tanggal 21 Juni 2018

Puspitawati, Herien, Konsep, Teori dan Analisis Gender. Bogor: IPB Press,2012

Qudâmah, Muwaffiq al-Dîn ibn, al-Mughnî, juz 11. Kuwait: Dâr 'Alim al-Kutub, 1997 
Rasyid, Sulaiman, Fiqh Islam. Bandung: Sinar Baru Algensindo [tth]

Sâbiq, Sayyid, Fiqh al-Sunnah. Beirut: Dâr al-Fikr, 1992

Santoso, Agus, Hukum, Moral dan Keadilan. Jakarta: Kencana Prenada Media Group, 2012

Shan'ânî, Muhammad ibn Ismâ'il al-Amîr al-, Subul as-Salam Syarh Bulûgh al-Marâm, penerjemah, Ali Nur Medan dkk, jilid 3. Jakarta: Darus Sunnah Press, 2013

Suyûthî, Jalâl al-Dîn al-, al-Jâmi’ al-Shaghîr. Bandung: al-Ma'arif, [tth]

Syarifuddin, Amir, Hukum Perkawinan Islam di Indonesia. Jakarta: Kencana, 2009

Umar, Nasarudin, Argumen Kesetaraan Gender Perspektif Al-Qur'an. Yogyakarta: Kreasi Wacana 1999

Undang-Undang Nomor 1 Tahun 1974 Tentang Perkawinan

Zuhaylî, Wahbah al-, al-Fiqh al-Islâmî wa Adillatuhu, Juz 7. Beirut: Dâr al-Fikr, 1989 